\title{
Seismic features of volcanic-hydrothermal complex structures and the influence of volcanism in the offshore petroleum system of the Sergipe-Alagoas basin
}

Ana Cristina M. Q. Coelho ${ }^{1}$, Miguel Tupinamba ${ }^{1,2}$, Gilmar Bueno ${ }^{1,3}$, Sergio Fontes ${ }^{1}$, Emanuele F. La Terra ${ }^{1}$, José Antônio Pereira ${ }^{1}$, Observatório Nacional - Programa de Pós-Graduação em Geofísica ${ }^{1}$, Faculdade de Geologia/UERJ'2, Faculdade de Geofísica/UFF ${ }^{3}$

\begin{abstract}
Copyright 2021, SBGf - Sociedade Brasileira de Geofísica.
This paper was prepared for presentation during the $17^{\text {th }}$ International Congress of the Brazilian Geophysical Society held in Rio de Janeiro, Brazil, 8-11 November 2021.

Contents of this paper were reviewed by the Technical Committee of the $17^{\text {th }}$ International Congress of the Brazilian Geophysical Society and do not necessarily represent any position of the SBGf, its officers or members. Electronic reproduction or storage of any part of this paper for commercial purposes without the written consent of the Brazilian Geophysical Society is prohibited.
\end{abstract}

\section{Abstract}

Oil exploration in complex plays, especially in offshore basins ultra-deep waters, requires an approach that integrates geological and geophysical knowledge. The application of explorational tools increases the probability of success in the search for reservoirs.

This work presents joint interpretations using geophysical methods to obtain a better exploratory understanding of the Sergipe-Alagoas sedimentary basin. Seismic and well data were integrated with Bouguer anomaly and total magnetic field intensity (TMI) data. The mapped seismic horizons were used as input data for modeling and 2D inversion of gravity and magnetic data. The modeled profiles are coincident with the interpreted seismic lines in order to generate an adjusted geological model.

Several mapped seismic facies evidence complex and diffuse structures that can be linked to magmatic and hydrothermal activity in the syn and post rift sedimentary pile. The modeled profiles inferred the presence of a large volume of volcanic rocks in the rifted extended margin of the Sergipe basin.
Based on the intrusive architecture interpreted from seismic data, we propose a link between magma reservoirs in the rift section and the complex structures in the post rift section of the basin. The magmatic and hydrothermal structures may be associated with tectonic reactivations and changes in surface deformation patterns in the SergipeAlagoas Basin. 